\title{
MARKETS, DEMOCRACY, AND ETHNIC CONFLICT
}

\author{
by Amy L. Chua*
}

Because my area of research is somewhat untraditional, I thought I would begin by saying a few words about the kind of work I do, and how it relates to the general theme of this year's Annual Meeting. As I'm sure you all know, over the last decade or so, Western lawyers and academics have been called upon to help restructure the fundamental institutions of the developing world to an extent unprecedented since decolonization after World War II. This restructuring of economic, political and legal institutions has been driven by two principal goals: marketization and democratization. Indeed, these two forces, markets and democracy, have come to be seen as global solutions to the intransigent problem of under-development.

But there is another force, much older and often darker, that plays an equally elemental role in shaping the societies of the developing world (and for that matter, the developed world): the force of ethnicity, or ethnic hatred. To date, there has been almost no systematic study of the interplay among these three forces: markets, democracy, and ethnicity. It is this interplay that has defined my academic project for the last several years. And much of my lecture today will be based on a recent article of mine, "Markets, Democracy, and Ethnicity: Toward a New Paradigm for Law and Development."

The central point I want to make today is that, contrary to conventional wisdom, markets and democracy may not be mutually reinforcing in the developing world. On the contrary, in many developing countries, the combined pursuit of marketization and democratization will often catalyze ethnic tensions in highly determinate and predictable ways, with potentially very serious consequences, including the subversion of markets and democracy themselves.

Now I'm going to lay out the specific arguments on which this thesis rests. I will start by drawing your attention to a fundamental and pervasive feature of developing societies that lawyers and legal academics - as well as institutions like the World Bank and the International Monetary Fund-have almost uniformly disregarded. Most developing countries have one or more ethnic minorities who, for widely varying reasons, historically have dominated economically the "indigenous" majorities around them.

These minorities, who may be economically dominant at the national or the regional level, have included the Chinese throughout Southeast Asia, Indians in East Africa and parts of the Caribbean, the Lebanese in West Africa and parts of the Caribbean, the Bamileke in Cameroon, the Ibo in Nigeria, the Kikuyu in Kenya, the Tutsi in Rwanda, Russians (along with Germans, Ukrainians, and Koreans) in Central Asia (in the former Soviet Union), Whites in South Africa, Whites in Zimbabwe, Tamils in Sri Lanka, Bengalis in Assam-the list goes on, quite strikingly, as I have documented. Moreover, a variation of the same phenomenon exists throughout much of pigmentocratic Latin America, where a minority of taller, lighterskinned, Spanish-blooded aristocrats historically have economically dominated the shorter, darker, Indian-blooded majorities around them, with a certain amount of "passing" in between. ${ }^{2}$ Now, to be clear, by economic dominance, I am talking about not just vague stereotypes but rather starkly disproportionate control of major sectors of the economy. So in Indonesia, for example, the Chinese during the Suharto regime made up roughly three percent of the population but controlled up to seventy percent of the private economy, under any

\footnotetext{
- Professor of Law, Duke University, Durham, N.C.

'Amy L. Chua, Markets, Democracy, and Ethnicity: Toward a New Paradigm for Law and Development, 108 YALE L.J. 1 (1998).

${ }^{2}$ See id. at 26; Amy L. Chua, The Privatization-Nationalization Cycle: The Link Between Markets and Ethnicity in Developing Countries, 95 CoLUM. L. REV. 223 (1995).
} 
number of measures. ${ }^{3}$ (That seventy percent figure has either dropped already or will be dropping soon, for reasons I'll explain.) Similarly, Whites in South Africa currently make up roughly fourteen percent of the population but own more than eighty-five percent of arable land and at least until very recently all of South Africa's largest conglomerates. ${ }^{4}$

At this point, I want to make two observations. First, the prevalence and visibility of economically dominant minorities in developing countries is a feature that starkly distinguishes the developing world from the developed world. In countries such as the United States, although some ethnic minorities have outperformed others, the economy is not dominated by any ethnic minority (whatever you might hear about Koreans or Jews, they do not control seventy percent of the U.S. private economy). The same is true throughout the industrialized West and, interestingly, in all of the so-called Asian Tigers (South Korea, Japan, Singapore and Taiwan): in all of these advanced economies, economically dominant minorities do not exist. ${ }^{5}$

Second, the reasons for economic dominance vary enormously. For example, some economically dominant minorities are former colonizers who used military force and the powers of the state to ensure their own dominance (e.g., Russians in Kazakhstan; Whites in South Africa). ${ }^{6}$ By contrast, the economic dominance of noncolonizer minorities such as the Chinese, Indians, and Lebanese cannot be explained in the same way. There are many theories that seek to explain the economic success of such "middleman minority" groups, ranging from colonial divide-and-conquer policies to the importance of social networking. But for purposes of my analysis today, the critical question is whether a particular economically dominant minority, for whatever reason, is market dominant-meaning that its economic dominance will not dissipate, but rather persist or even increase with market-oriented reforms.

It is important to stress that not every economically dominant minority is market dominant. The economic power of a given minority may be such that this power will erode or disappear under market conditions. This might be case with Russians in Kazakhstan, for example (to the extent that they owe their economic dominance principally to discriminatory tsarist or Soviet-era policies). But if a market-dominant minority is present in a given country, important consequences follow. Most crucially, the presence of a market-dominant minority in a given developing country means that markets and democracy will not be mutually reinforcing. This is because in developing countries with a market-dominant minority, markets and democracy will tend to benefit different ethnic groups: markets will (by definition) benefit the market-dominant minority, while democratization will increase the power of the relatively impoverished majority.

As a result, the combined pursuit of markets and democracy will produce an ethnically charged, highly unstable situation. In my Yale Law Journal article, I develop a model to explore the likely consequences of pursuing markets and democracy in these circumstances. I argue that in countries satisfying certain specified conditions, including economic underdevelopment and the presence of a market-dominant minority, marketization and democratization will, respectively, produce highly determinate and potentially highly destructive ethnoeconomic and ethnopolitical consequences, along the following lines.

${ }^{3}$ See Leo Suryadinata, Indonesian Policies Toward the Chinese Minority Under the New Order, 16 AsiaN SURV.770, 770 (1976); A Taxing Dilemma, ASIAWEEK, Oct. 20, 1993, at 53 (citing a Sakura Bank-Nomura Research Institute study).

'See Chua, supra note 1, at 65; Gumisai Mutume, South Africa Development: Not Yet Growth With Equity, INTER PRESS SERV., July 17, 1996; Sudarsan Raghaven, Black Owners Take a Piece of a Major South African Firm, CHRISTIAN SCI. MONITOR, Sept. 16, 1996, at 7.

s See Chua, supra note 1 , at 27-28.

${ }^{6}$ TED GURR \& BARBARA HARFF, ETHNIC CONFLICT IN WORLD POLITICS 24 (1994). 
First, marketization - far from having the civilizing effect that Montesquieu envisionedwill tend instead to catalyze ethnic animosities, by maintaining or even exacerbating the disproportionate wealth of the "outsider" minority and fomenting ethnic envy and hatred among the impoverished majority."

Next, with democratization, this ethnoeconomic resentment will tend to be transformed into a potent ethnonationalist movement, in part because politicians will have powerful incentives to scapegoat the economically dominant minority and foment ethnic hatred. Characteristically the result of this process will be the emergence of an aroused ethnically defined majority who, perceiving markets as solely or principally benefiting the resented minority, demands that the minority's economic dominance be put to an end, and the nation's wealth and identity reclaimed for its "true owners."

Once this dynamic is in play-pitting a democratically mobilized, impoverished, "indigenous" majority against a resented, economically dominant, "outsider" minority-one of three (non-exclusive) outcomes becomes highly probable: (1) an antimarket backlash targeting the market-dominant minority; (2) actions aimed at eliminating the market-dominant minority (for example, through expulsion or atrocity); or (3) a pro-market retreat from democracy.

The first outcome-an ethnically targeted antimarket reaction-has been extremely common in the developing world. Time and again, developing-world governments-both authoritarian and democratic-have tried to "correct" the problem of an economically dominant minority by intervening in the market, either by nationalizing assets and industries controlled by the resented minority, or by imposing ethnically based restrictions on commercial activity. Ethnically targeted nationalizations have occurred throughout Southeast Asia and Latin America ${ }^{9}$ At the same time, ethnically based economic restrictions-for example, restrictions on corporate ownership, licensing, employment opportunities and landownership - have also been common, particularly in Asia and Africa. So, for example, after World War II, in Thailand, Chinese were excluded from twenty-seven occupations; in Cambodia from eighteen.

Historically, these ethnically targeted nationalizations and commercial restrictions have typically backfired. A vivid illustration of this can be found in Indonesia's recent food crisis. Until May 1998, Indonesia's rice distribution network was dominated by ethnic Chinese traders, who had a system that was quite effective, although certainly not free of corrupt profiteering. After Suharto's resignation, the government of Bacharuddin Jusuf Habibie, very much supported by majoritarian, anti-Chinese sentiment, canceled rice distribution contracts with hundreds of ethnic Chinese businessmen and awarded them instead to indigenous entrepreneurs, many of whom had little or no experience in the field. ${ }^{10}$ The results were disastrous, part of a food crisis in which tens of millions of Indonesians were reportedly eating only one meal a day. "The new rice "cooperatives," run by the state, have been saturated with corruption and inefficiency-and scandal: one official was accused in 1998 of trying to smuggle 1,900 tons of rice to Malaysia while his own constituents were starving. Predictably, indigenous officials and businessmen have secretly resumed subcontracting work out to Chinese traders. ${ }^{12}$

A second possible outcome of pursuing markets and democracy in the face of a resented "outsider" market-dominant minority (together with the other specified conditions) is elimi-

\footnotetext{
${ }^{7}$ See Chua, supra note 1 , at $37-41$.

'See id. at $42-47$.

'See Chua, The Privatization-Nationalization Cycle, supra note 2.

${ }^{10}$ See The New Indonesia: The Business of Hatred, SYDNEY MORNING HERALD, Oct. 28, 1998.

"See Indonesia's Anguish, N.Y. TIMES, Oct. 16, 1998, at A26.

${ }^{12}$ See The New Indonesia, supra note 10.
} 
nationism, which also has been a depressingly familiar occurrence in the Third World. There are numerous instances in which a self-proclaimed "indigenous" majority has tried to eliminate an economically dominant ethnic minority - whether by forced assimilation or by expelling the minority (as Idi Amin did with Uganda's Indian and Pakistani community in 1972, after first confiscating their assets), or finally by killing off the minority, through ethnic pogroms or genocide-the fate suffered by the Tutsi in the mid-1990s in Rwanda. ${ }^{13}$

The third possibility is a retreat from democracy. This a pro-market outcome. Here, rather than defer to the majority's demand for policies undercutting the economic dominance of the resented minority, the government of a developing country might instead seek to cultivate that minority in defiance of the democratic will.

This retreat from democracy can take a number of forms. First, the government may be "bought out" by the wealthy minority. Alternatively, the leader of a developing country might wish to harness the market-dominant minority's skills and experience to fuel the country's economy, and toward that end might disband parliament, cancel elections, or take other measures suppressing political competition. ${ }^{14}$ These two scenarios are not mutually exclusive, as General Suharto's market-oriented thirty-year autocracy in Indonesia illustrates. Like Ferdinand Marcos in the Philippines, Suharto had a symbiotic relationship with his country's Chinese business community. Throughout his rule, Suharto not only protected the Chinese politically but directed lucrative business opportunities to them. ${ }^{15}$ The Chinese returned these favors, both by fueling the country's economy and by adding enormously to Suharto's personal wealth-to an extent that is now notorious. ${ }^{16}$

But as already noted above, these arrangements between Suharto and the ethnic Chinese provoked massive, widespread resentment among the pribuni majority, where both antimarket reactions and even eliminationist impulses have been in play since May $1998 .{ }^{17}$ According to some reports, many Indonesians say it would be worth losing ten years of growth to "get rid of the [Chinese] problem once and for all."18 Indeed the vicious anti-Chinese violence that erupted after Suharto's resignation, together with state-condoned anti-Chinese rhetoric, discrimination, and confiscation, led many Sino-Indonesians to leave the country and prompted a massive flight of Chinese-controlled capital, estimated at $\$ 20-\$ 40$ billion. The Habibie government's proposal for a "People's Economy" "involves the breaking up of Chinesedominated enterprises and transferring them to the long-suffering masses using cooperatives and small- to medium-scale industries as receivers." Malaysia-style ethnically based preferences for indigenous Indonesians ${ }^{20}$ which, as I have discussed at length elsewhere, I actually favor despite obvious problems with such schemes. ${ }^{21}$ Still more problematically, analysts are beginning to see-as I argue in my recent article ${ }^{22}$ that the more democratic a country such as Indonesia becomes, the more likely it is that these

${ }^{13}$ See Chua, supra note 1 , at 51-54.

${ }^{14}$ See id. at 54-56.

is See William Ascher, From Oil to Timber: The Political Economy of Off-Budget Development Financing in Indonesia, 65 INDON. 37, 53 (1998).

${ }^{16}$ See id. at 54-55.

${ }^{17}$ See David Lamb, Terrorized Ethnic Chinese Still on Edge in Indonesia Southeast Asia, L.A. TIMEs, Oct. 3, 1998, at A4.

${ }^{18}$ Ravi Velloor, Fix Chinese Issue, Indonesia Told, NEW STRAITS TIMES, Oct. 10, 1998, at 2.

${ }^{19}$ Abdul Razak Ahmad, People's Economy to the Rescue? NEW STRAITS TIMES (MALAYSIA), Dec. 21, 1998, at 6.

${ }^{20}$ See Tom McCawley Serang, A People's Economy, ASIAWEEK, Dec. 18, 1998, at 62.

${ }^{21}$ See Chua, supra note I, at 62-63,77; Chua supra note 2, at 292-96.

${ }^{22}$ Chua, supra note 1. 
antimarket and eliminationist impulses will be mobilized. ${ }^{23}$ And let me repeat that the situation in Indonesia is just one example of a phenomenon that exists throughout the developing world.

To conclude, international organizations such as the World Bank and the International Monetary Fund, as well as lawyers and legal academics involved in the developing world, have not, in my view, focused enough on the historical, distributional, and particularly ethnodistributional dimensions of their work. Why this is so is itself fascinating. Legal practitioners probably view ethnic tensions as lying far beyond the scope of their responsibility. Economists (and law-and-economics scholars) involved in market reforms also tend to treat ethnic conflict as beyond the scope of their analyses; although all behavior can be described as preferencemaximizing in a tautological sense, the "preferences" and behaviors associated with ethnic hatred escape the kind of rationality assumed in most economic models. Human rights lawyers do confront ethnic conflict, for example in context of war crimes. But because of the humanitarian nature of their work, human rights lawyers tend to focus on groups that are both politically and economically oppressed, and for this reason they too tend to overlook the problem of economically dominant ethnic minorities. Finally, and more generally, Western discomfort with potentially invidious ethnic generalizations may go a long way in explaining the neglect of the ethnic dimensions of markets and democracy in the developing world.

In any event, for whatever reason, today's dominant international policy approach in the developing world regards ethnic conflict as just another aspect of underdevelopment, which the universal prescription of markets and democracy is supposed to cure. But this is a potentially fatal error. The ethnic dynamics of many post-socialist and developing countries introduce deep tensions into the very project of marketization and democratization, which, if unaddressed, threaten to undermine the long-term success of the development project.

${ }^{23}$ See Velloor, supra note 18 , at 2. 